\title{
Ania Spyra: Self-Indulgence is the American Word for Flair
}

In high school, I was the student who had to read her essays aloud in class. But wait, did you, in the U.S., also have those students, favorites of your literature teachers, who were asked, after each assignment, to show others what a perfect essay should look like? I hope you know what I am talking about. I hope you understand how uncomfortable that position can be for a gangly teenager unsure of her position in the high school popularity rankings. But on the other hand, of course I liked to be good at something. I knew what writing was about. It was an important part of who I was. Teachers saw a bright future of bestsellers for me. My sentences were long, complex, emphasizing the intricacy of my thought. I never repeated a word in adjacent sentences, sometimes in a whole essay, but made sure instead that my descriptions were always new, always more nuanced. I loved rhetorical questions and ellipses, and ended paragraphs with them. I played with words, alliterated whole sentences, or multiplied adjectives for a greater rhetorical effect, my sentences striking, posed, poetic. I was writing with polot, or flair, which Eva Hoffman sees as a combination of "meanings of dash, inspiration and flying" (71). Flair is the keyword in Polish stylistics; it is the key that opens the hearts of literature teachers. Flair means a density of style and abstruseness of argumentation.

Wait, those do not seem to mean good style to you? See, that was my greatest problem too when I arrived in the United States to pursue my Ph.D. in English. My English was fluent; the shock of difference was not in language itself. But my idea of what style was had nothing to do with the straightforward argumentation that the American composition manuals recommended and my native-speaking instructors expected. I felt gagged. Now, look how short my sentences can be.

You would think that coming to the U.S. with a Master's Degree in English, even if from a Polish university, I had heard of the differences in writing style between the two countries. There were moments of reckoning in the five years I spent studying at the University of Silesia. One of those moments was when my school hosted a Fulbright scholar, and his wife volunteered to teach composition to sophomores. She was the bane of all of us poetic writers-and there were many of us. Suddenly instead of the 'fives' we were used to (the highest grade in the Polish educational system), we got three and seventy-five hundredths or some other cruel fraction, far from perfection. My first grade with her was three and twenty-five hundredths, I remember to this day, painfully. Since a two was the passing grade, I was not so far from just passing. She most disliked the educated ellipses we were using: "As Heraclitus said, you do not walk twice..." she would ask us to finish the sentence. She wanted organization, thesis statements, topic sentences none of us had any idea about. And we simply did not agree with her style. All our other professors-like us Poles schooled in English-valued what we valued: finesse and flair. We tried to appease her, but wrote with complexity and puns for our other classes. And as soon as the semester ended we forgot what a topic sentence was.

The other moment of reckoning was when I asked an American teaching conversation at my University to review my M.A. thesis. I was at that point in the 
application process to the University of Iowa, or might have even received my acceptance letter by then, so he knew I was in for a total change of style and wanted to warn me against the shock I was to experience continuing my studies in the U.S. He gave me some pointers: do not overuse the thesaurus; stick to unadorned vocabulary and simple sentences; don't be afraid of calling a spade a spade even if you have to do it in three consecutive sentences. But also he told me: "Do not give up your style when you get to the U.S., they will want to make you write like a scientist, but you are a literary critic; enjoy the words, show others that you enjoy your writing tooAbove all I enjoyed alliteration and punning: the easy way to introduce poetry into my academic work. My Master's thesis bore the title: "Rites of Writing: Liminality in J. M. Coetzee's Novels." My first publication-a short story that came out of a creative writing workshop I took while at the University of Stockholm-I titled "Tears while Tearing." I even remember getting compliments on the title in the class. Now, because of the self-indulgent title, I am ashamed to include the publication on my Curriculum Vitae.

In my first semester at the University of Iowa, I wrote a paper on images of moths in Jean Rhys and abortion as a metaphor for migration in Jamaica Kincaid. How original of me! How baffled my professors must have been. Where was the argument beyond the play with imagery? Where was the postcolonial insight into these Caribbean writers? My professors were gracious, I have to admit, maybe aware of the stylistic shift I was experiencing, maybe simply not used to giving bad grades to graduate students? The infamous American grade inflation cushioned my fall from the heights of my Polish writerly excellence. I would have been disheartened if it didn't; I probably would not be writing this now.

Even without bad grades, I felt my writing did not fit in. My professors' penciledin questions were enough to make me realize this. I struggled to reshape my writing, but only when I became a literature instructor myself did I learn about "good" style in the American vein. I suddenly had to teach what I not yet fully believed in. I read style manuals: MLA, Chicago, Strunk. I became a stickler for structure. I found that there were students with flair here too and that like myself they had problems with arguments. Argumentation is so abrasive and angry, and for me literature and its criticism were all about the Barthesian plaisir du texte.

I started to feel gagged. When I look back at it now, I am not surprised that during my first two years in grad school, my research focused on hysteria: speechlessness being one of its classic symptoms. If my writing had to be politically engaged, the crossroads of psychoanalysis and feminism was where I found it easiest to turn anger into argument. But I felt as gagged as suffragettes force-fed during a hunger strike. I reviewed what I had written in my five years at Silesia, and now saw it as philosophizing with no point. What was worse, I came to see the majority of foreign academic writing as disorganized, self-absorbed... self-indulgent.

Self-indulgence is the American word for flair. I learned to pronounce it with the same contemptuous grimace I saw on my colleagues' faces. I learned to apologize for puns. I learned to see wordplay and metaphors as redundant in scholarly essays. I came to avoid provocative statements, even if they sounded pithy and smart. I 
ironed out ambivalences lest they confuse the reader. Yet in this essay I keep provoking you, hoping irony will conceal the pain of seeing my native stylistics as hollow. I am ambivalent, and you confused, because I cannot explain how it feels to exchange something I valued for something else I value as much. A win-win situation, you would think, and yet this exchange was a loss.

What I lost in translation was my writerly confidence. My internal critic is louder than most; she speaks both languages and can ridicule me in both. But the discomfort with the stylistic shift also provided the impetus for my research, because I wondered if there were other writers who suffered like myself in the rifts between languages and stylistics. I found affinity with post-colonial writers debating their voicelessness in the face of the colonial discourse. I empathized with immigrant and minority writers caught between home and target languages. I read language memoirs: Nabokov, Hoffman, Derrida. I searched for bilinguals and translinguals. What disappointed me, however, was that most of them gave in to the target or imperial language just like I did. I wanted to see rebellion.

That is when I found the topic of my dissertation, and wrote it with vengeance. The writers I focused on rejected monolingualism and translation, stylistics and its ideas of what was proper in writing. They juggled many languages in the same sentence and wrote with varied styles in the same poem or novel. Jolas, BrookeRose, Shange, Chávez-Silverman were the rebels I did not dare to be. Although I wrote my dissertation against the style that I had mastered, I did not even dare to intersperse the critical chapters with personal essays, as I had originally planned. Even though I received a lot of encouragement in a department where non-fiction writing was part of the curriculum, I gave the idea up on my own. I did not want a creative hybrid because I was afraid to admit a personal bias in my scholarly U.S. dissertation. Writing about the multilingual rebels was enough to convince me that I did not fully give in to English and its stylistics.

Alice Kaplan notes in her article "On Language Memoir" that the stories of language learning are inherent to stories of upward mobility both for immigrants and those who learn languages for a variety of other motivations, like a wish or need to escape the narrowness of their patriotic allegiances. Mine is not a story of language learning, rather a story of developing a new writing persona; but "I have arrived" in a similar way, my upward mobility attested to by the national fellowship I won for completion of my dissertation, by the letters that follow my last name. When I read Virginia Dominguez describe the ethical dilemma she encounters when she has to advise students like myself on how to write to be successful, knowing it is also an imperial practice, I think of the nuanced advice I got from my advisors when they helped me jump through the hoops of academic requirements. We often talked about writing. I remember the endless conversations about the clarity of arguments, about grammar (how illogical "a lot of" followed with a plural verb seemed to me-a single lot should be followed with a singular verb), even about semi-colons.

What seems essential to me now is that these conversations not only reshaped my writing, they also influenced how my advisors read. After my Ph.D. defense one of my advisors told me that she found some of my sentences hard to follow, 
but she continued: "They sounded off and my first impulse was to suggest changes to them. But after I thought through the logic behind them, I could perfectly understand why you chose the formulations you did. They were correct; I could not correct them. They were simply your style." It would add a nice flourish to finish this essay with an assertion that what she called my style was a trace of my Polish flair, but I will actually never know which sentences sounded unusual, because she did not mark them; and I will never read like a native speaker, even though I try to write like one. When I read a review berating Arundhati Roy's sentence fragments or Salman Rushdie's puns or hear my students complain about Joseph Conrad's syntax, I know they still have to learn to read for that other level of logic. Reading across stylistic differences is an exercise in comprehension across cultural boundaries; at its best, it makes us sensitive to different ways of thinking. What is gained in translations such as mine, then, is not only the paradox of an accent audible in writing, but also the opportunity to engage with an other.

\section{Works Cited}

Derrida, Jacques. Monolingualism of the Other, or, The Prosthesis of Origin. Trans. Patrick Mensah. Stanford, CA: Stanford UP, 1998.

Dominguez, Virginia R. "Wiggle Room and Writing." Iowa Journal of Cultural Studies. Online Forum. 2009. Rpt. in this issue of Iowa Journal of Cultural Studies.

Hoffman, Eva. Lost in Translation: A Life in a New Language. New York: Penguin, 1989.

Kaplan, Alice. "On Language Memoir." Displacements: Cultural Identities in Question. Ed. Angelika Bammer. Bloomington: Indiana UP, 1994. 59-70.

Kramsch, Claire. "The Multilingual Experience: Insights from Language Memoirs." TRANSIT 1.1 (2005): 1-12. <http://german.berkeley.edu/transit/2005/ index.html.>

Kellman, Steven G. The Translingual Imagination. Lincoln: University of Nebraska Press, 2000.

Nabokov, Vladimir. Speak, Memory. New York: Putnam, 1966.

Ania Spyra is an Assistant Professor of English and Comparative Literature at Butler University. She is currently working on a book on multilingual experiments in transnational literature.

\section{Bimbisar Irom: Writing in from the outside: Reflections on the "Oh No! Syndrome" and writing pedagogy from a non-native teacher}

This essay is intended to reflect on the experiences of non-native speaker teachers of English (commonly referred to as NNSTs by linguists and educationalists) in the writing classroom in the United States. Although the essay contains many of my observations as a teacher of writing in the United States, my hope is to leap beyond the personal to provide some insights that might prove useful, both for native and non-native teachers, in negotiating the terrain we call the writing classroom. I am 